\title{
FRANCESCA FERRANDO: Philosophical Posthumanism
}

London: Bloomsbury Academic, 2019. 272 s. ISBN 978-1-3500-5950-4

DOI: https://doi.org/10.31577/WLS.2021.13.1.8

Francesca Ferrando je významnou osobnostou súčasného filozofického diskurzu. $\mathrm{V}$ rámci neho sa koncentruje najmä na posthumanizmus, ktorý považuje za filozofiu dnešnej doby (1). Knižná monografia s názvom Philosophical Posthumanism je výsledkom jej uvažovania za posledných desat' rokov. Ide o upravený preklad pôvodnej knihy Il Postumanesimo Filosofico e le sue Alterità (2016), ktorá vznikla na základe autorkinej ocenenej dizertačnej práce s názvom The posthuman: Philosophical posthumanism and its Others (2014); získala za ňu cenu Sainati (cenu prezidenta Talianskej republiky). Zameriava sa $\mathrm{v}$ nej na rodovú problematiku (gender studies) a na teóriu kyborgov (cyborg theory), pričom skúma predovšetkým anglický pojem posthuman. Ferrando je zároveň zakladatelkou Globálnej posthumánnej siete (Global Posthuman Network, 2012). Jej záujem o analýzu tohto pojmu vyplýva z otázky, či obrat paradigmy v ontologickej a epistemologickej percepcii človeka, ktorý filozofia posthumanizmu vytvára, možno označit za posthumánny. Autorka metodologicky skúma, či historicky pôvodné percepcie človeka, ako aj vztah človeka $k$ vonkajšiemu svetu, mení filozofia posthumanizmu natolko, že už viac nemožno hovorit’ o človeku, ale skôr o postčloveku (posthuman). Nezaujíma ju však iba to, na čo pojem posthuman vo filozofii historicky odkazuje alebo čo zastrešuje, ale aj to, ako sa človek v antropocénnej dobe môže stat' (nielen) metodologicky posthumánnym.

Analýza filozofického posthumanizmu ako aktuálnej témy vo filozofii je v monografii reflektovaná $\mathrm{v}$ dvoch hlavných rovinách, ktoré zároveň vytvárajú jej základný tematický rámec. Prvú rovinu predstavuje ana- lýza posthumanizmu ako post-humanizmu. $\mathrm{V}$ tejto rovine je posthumanizmus konceptuálne uchopený ako druhá generácia postmodernizmu. V tomto význame kopíruje všeobecnú metódu filozofického postmodernizmu, ktorá je primárne vybudovaná na dekonštrukcii pôvodne humanistického konceptu človeka. Autorka vytvára nielen historickú reflexiu radikálnej dekonštrukcie pôvodne humanistického pojmu človek, ale svoj záujem orientuje aj na revíziu (pre posthumanizmus falošnej) druhovosti, teda kritiky určitej nadradenosti a privilegovanosti biologického druhu Homo sapiens nad inými biologickými druhmi. Prvá rovina analytického prístupu k post-humanizmu je tak naplnená kritikou rozdielu. Je to práve fenomén diferencie, ktorý je v optike post-humanizmu kritizovaný a zároveň vnímaný ako niečo, čo treba metodologicky eliminovat a efektívne nahradit. Takáto optika nazerania na človeka a na jeho postavenie vo svete odstraňuje rozdielnosti vyplývajúce $\mathrm{z}$ nadradeného humanistického (sexizmus, rasizmus), ako aj antropocentrického (speciesizmu) prístupu $\mathrm{k}$ vonkajšiemu svetu.

Druhá rovina monografie predstavuje analýzu posthumanizmu ako posthuman-izmu. Analýza sa sústreduje najmä na chronologickú rekonštrukciu používania klúčového pojmu posthuman v súčasnej akademickej diskusii. Okrem toho, že tento pojem v knihe figuruje ako zastrešujúci pre viaceré filozofické izmy 20. a 21. storočia, zároveň predstavuje vztah človeka k aktuálne existujúcim, emergentným či dokonca špekulatívnym technológiám ,,as in the case of regenerative medicine, radical life extension, mind uploading, and cryonics" (3; ako v prípade regeneratívnej medicíny, radikálneho predí- 
ženia života, nahrávania mysle a kryoniky; prel. P. B.). Vplyv technológií na človeka sa tak v perspektíve posthuman-izmu primárne spája s fenoménom premeny. Jednak možnej premeny človeka a jeho prirodzenosti, ako aj premeny vztahu či postoja človeka $\mathrm{k}$ technológiám. $\mathrm{V}$ takejto perspektíve posthumanizmu sa totiž človek vzhladom na možnosti rôznorodých technológií môže tak radikálne transformovat', že sa $\mathrm{z}$ neho napokon stáva postčlovek (posthuman).

Komplementárnost' fenoménov diferencie a premeny vytvára $v$ knihe nielen filozofický či metodologický, ale aj poetický, ba priam umelecký rys základného chápania filozofického posthumanizmu. Jedna $z$ metód analýzy filozofického posthumanizmu sa riadi najmä feministickým prístupom, ktorý patrí $\mathrm{k}$ metódam uplatňovaným v tejto filozofii. Ide hlavne o pokračovanie v metodologickej línii filozofky Rosi Braidotti, ktorá upozornila na uplatňovanie nového spôsobu premýšlania o hmote: „[as] an assumption about the vital, self-organizing, and yet non-naturalistic structure of living matter itself " (1; ako predpoklade o vitálnej, samoorganizujúcej sa, a predsa neprirodzenej štruktúre samotnej živej hmoty; Rosi Braidotti: The Posthuman, 2013; prel. P. B.). Takto inšpirovaná metóda umožňuje nahradif antropocentrizmus novým súborom väzieb človeka $\mathrm{k}$ iným bytostiam (ludským či neludským), druhom, technologickým artefaktom či iným zatial' neznámym skutočnostiam. Ferrando však uplatňuje aj prístup, ktorý vyplýva zo širokej kolekcie otázok. Každá kapitola monografie totiž predstavuje určitý tematický rámec, ktorý je doplnený o niekol'ko autorkiných otázok. Práve táto metóda robí z knihy Philosophical Posthumanism publikáciu vhodnú nielen pre akademickú obec, ale aj pre širšiu verejnost'. Analytický prístup Ferrando k hladaniu odpovedí na dané otázky pripomína zrod vítaného obnovenia sokratiky vo filozofii posthumanizmu, pretože metodologicky pretvára myslenie bežného človeka, zbavuje ho historicky chybných dogiem a zároveň ho učí zahrnút posthumanistický obrat do kríz 21. storočia.
Monografia je rozdelená na tri hlavné časti, $\mathrm{v}$ rámci ktorých sú jednotlivé kapitoly navzájom prepojené. Prvá čast' knihy sa zameriava na určenie základného rámca pre filozofický posthumanizmus, čím sa primárne orientuje na spomínaný rozklad pôvodne humanistického významu pojmu človek. Epistemologické obmedzenia človeka sú nahradené nehierarchickou perspektívou postčloveka (posthuman), ktorá spočíva v skúsenosti s inými než ludskými bytostami, $s$ umelou inteligenciou, robotikou či s doposial' neznámymi formami života. Takto predefinovaná integrácia pôvodne humanistického pojmu človek sa orientuje na analytický výklad pojmu postčlovek (posthuman). Pojem posthuman následne zahŕňa významy vedecko-technologického či biotechnologického vývoja 20. a 21. storočia, kde sa autorka zameriava najmä na zdôraznenie podobností, ako aj rozdielností medzi jednotlivými školami myslenia, ktoré referujú o pojme posthuman. Sleduje pritom kontrasty medzi posthumanizmom filozofickým, kultúrnym a kritickým, transhumanizmom extropianistickým, liberálnym a demokratickým, novým materializmom s feministickým vplyvom, antihumanizmom a jeho objektovo orientovanou ontológiou či metahumanizmom. Genealógie, analógie a vzájomné prekrývanie týchto nových izmov zároveň vyústujú do konceptuálneho uchopenia a zodpovedania pôvodnej otázky: Čo je filozofický posthumanizmus?

Druhá čast' knihy sa zameriava na koncept človeka $\mathrm{v}$ zmysle sémantiky a pragmatiky podporujúcej pojem človeka. Analýza prebieha cez skúmanie dvoch rovín pôvodného pojmu človek: jednak cez latinskú etymológiu pojmu humanitas a druhotne cez taxonomickú klasifikáciu človeka ako Homo sapiens. Ferrando takto zvolený prístup považuje za dôležitý z dvoch dôvodov. Na jednej strane je pre koncept posthuman potrebné porozumiet’ genealogickému vztahu k človeku, teda vykonat' určitý náhlad do historického, ako aj filozofického významu pojmu človek. $\mathrm{Na}$ strane druhej treba porozumiet' kritickému významu pridanej predpony post- ako spô- 
sobu na odstraňovanie pôvodných a falošných dichotómií, hierarchického usporiadania či opozičného nahliadania.

Tretia čast' knihy sa zameriava najmä na skúmanie $\mathrm{v}$ oblasti biológie $\mathrm{s}$ explicitným dôrazom na pojem život, ako aj na bioetiku či biotechnologický vývoj patriaci do posthumanizmu. Ferrando biologickú evolúciu vníma ako určitú technológiu existencie, kde každý materiálny prejav možno chápat’ ako bytostné existenčné pôsobenie bez pridaného rozdielu: „,[E]volution does not imply any type of hierarchy nor progression from inferior to superior organisms, nor does it support any essentialism or strict dualism; rather, it complies with a hybrid, processual perception of existence, which is in tune with Philosophical Posthumanism“ (124; Evolúcia neznamená žiadny typ hierarchie ani postup od podradných $\mathrm{k}$ nadradeným organizmom, ani nepodporuje žiadny esencializmus či striktný dualizmus; skôr je v súlade s hybridným, procesným vnímaním existencie, ktoré súznie $\mathrm{s}$ filozofickým posthumanizmom; prel. P. B.). Antropocentrická volba orientovaná smerom k významu bios (pojem vnímaný ako osobitý pre človeka, kedže súvisí s pojmom logos; ide o život (bios), ktorý dáva životu zmysel a rozpoznáva ludí ako ludí; pozri viac 109 - 110) je náležite nahradená volbou vitacentrickou, odkazujúcou $\mathrm{k}$ významu pojmu $z o \bar{e}$ (pojem spoločný pre všetky živé bytosti vrátane zvierat, ludí či bohov; možno ho definovat ako „holý život“, vztahujúci sa k životu všeobecne, bez charakterizácie; pozri viac 109 - 110). Tento konceptuálny prechod $\mathrm{k}$ vitacentrizmu je v poslednej časti knihy demonštrovaný príznačným myšlienkovým experimentom The Posthuman Multiverse, ktorého jadrom je dekonštrukcia paradigmy Ja/Iní (Self/Others paradigm), čím monografia vytvára inovatívny prístup $\mathrm{k}$ realite.

Francesca Ferrando svojou knihou Philosophical Posthumanism prispieva ku kritike antropocentrizmu a taktiež porozumeniu problematickosti geologickej epochy antropocénu pre každú oblast vedeckého záujmu. Opisuje hlavné riziká, ktoré vyplývajú z predstavy nadradenosti, ako aj vylepšovania ludí pomocou technológií. Pojem posthuman $\mathrm{v}$ knihe figuruje najmä v súvislosti s metodologickým obratom a opustením názorov a postojov, ktoré môžu viest' $\mathrm{k}$ diskriminácii človeka a iných bytostí $(5-6)$. A práve preto $s$ istou mierou nadsádzky smieme predpokladat', že ak raz na Zem zavítajú mimozemské neludské bytosti, kniha Philosophical Posthumanism môže zohrávat úlohu dokonalého bedekra, v ktorom sa dozvedia, že tí, na ktorých sa pozerajú, by už nemali byt' ludia, ale postludia.

Zdá sa teda, že ak chce ludstvo oslavovat' svoju existenciu, potom azda iba v intenciách filozofického posthumanizmu, pretože iná budúcnost' ako metodologicky či technologicky posthumánna nás podla Francescy Ferrando už nečaká: „(I)t is now clear that Humans are no longer the most important things in the Universe. This is something the Humanists have yet to accept“ (56; „Teraz je zrejmé, že ludia už nie sú to najdôležitejšie vo vesmíre. Toto je čosi, čo musia humanisti ešte prijat"; prel. P. B.). Ferrando prístupným spôsobom predstavuje základné tézy súčasného posthumanizmu, čím do takto orientovaného filozofického diskurzu vnáša analytickú jasnost' a zrozumitelnost' jednotlivých izmov 20. a 21. storočia. Zvolený prístup autorky je zároveň originálny, kedže monografia okrem potreby metodologicky opustit pôvodne humanistický koncept človeka predstavuje príklady z praxe, pomocou ktorých človek 21. storočia lepšie porozumie svojmu reálnemu pôsobeniu, ako aj miestu vo svete.

PAVLÍNA BAKOŠOVÁ Univerzita sv. Cyrila a Metoda v Trnave Slovenská republika 